Andrzej Skwarski

Akademia im. Jakuba z Paradyża

w Gorzowie Wielkopolskim

\title{
Służby specjalne Rosji podstawowym narzędziem realizacji polityki wielkomocarstwowej Kremla.
}

Wiara $w$ możliwość Rosji parlamentarno-demokratyczno-republikańskiej wydaje mi się tak dalece śmieszna, że lekceważenie umysłowości ludzi, którzy moga w coś takiego wierzyć, zabija we mnie współczucie do tragizmu, który się mieści w tej beznadziejności.

Stanisław Mackiewicz

$\mathrm{W}$ marcu 2018 roku w Salisbury trzech oficerów rosyjskiego wywiadu wojskowego Głównego Zarządu Wywiadowczego Sztabu Generalnego Sił Zbrojnych Federacji Rosyjskiej (GRU) podjęło próbę zabójstwa byłego agenta tej służby Siergieja Skripala i jego córki. Z inicjatywy Londynu sprawa stanęła na forum Rady Bezpieczeństwa ONZ, nabierając znaczenia globalnego. Państwa zachodnie, w tym Stany Zjednoczone, w ramach solidarności z Brytyjczykami potępiły działania Rosji. W sumie z USA oraz innych państw, które potępiły zamach, wydalono ponad 150 dyplomatów rosyjskich. Ze względu na podległość GRU prezydentowi Rosji, Władimir Putin w opinii rządu brytyjskiego, ponosi bezpośrednią odpowiedzialność za zamach. Nie jest to pierwszy zamach zorganizowany przez służby specjalne Rosji poza granicami kraju. W 2006 roku rosyjski biznesmen Dmitrij Kowtun oraz były agent rosyjskich służb specjalnych Andriej Ługowoj dokonali zamachu na Aleksandra Litwinienkę. Dokonali tego przy użyciu niezwykle groźnego radioaktywnego izotopu Polonu 210, którego zdobycie trudno wytłumaczyć inaczej niż za pośrednictwem instytucji państwowej. Ten, w przeszłości funkcjonariusz służb specjalnych Rosji, demaskował prawdę o korupcji w Federalnej Służbie Bezpieczeństwa (FSB) w czasach, gdy jej szefem był Putin. Oskarżał też FSB o serię ataków bombowych na budynki mieszkalne w Rosji w 1999 roku. Ostatecznie o dokonaniu zamachu mógł zdecydować fakt, że w ostatnich miesiącach przed 
śmiercią próbował ujawnić rzekome powiązania między bliskim otoczeniem Putina, a rosyjską mafią ${ }^{319}$.

Zabójstwa polityczne to tylko jedna z metod stosowanych przez służby specjalne Rosji w celu kreowania wydarzeń pozytywnych dla nadal wielkomocarstwowej polityki Kremla. Doskonałym przykładem szerokiej palety stosowanych środków są te użyte w stosunku do Ukrainy w celu zdestabilizowania sytuacji politycznej, gospodarczej, społecznej, oraz pozycji na arenie międzynarodowej. Na poziomie międzynarodowym były to: destabilizacja sytuacji wewnętrznej i polityki zagranicznej Litwy, Łotwy, Estonii, Polski, Białorusi, Słowacji, Mołdowy, Czech i Niemiec, ataki ekonomiczne, kampanie informacyjne i destabilizacja gospodarcza na odcinku wschodnim i zachodnim, ataki, dyskredytacja, uniemożliwianie wykorzystania obowiązków służbowych, kampanie informacyjne, protesty przeciwko pracy zagranicznych ekspertów na Ukrainie. Ponadto: kontynuacja wojny informacyjnej i wojny psychologicznej przeciwko Ukrainie w państwach zachodnich z wykorzystaniem kremlowskich mediów propagandowych, wykorzystanie kwestii mniejszości ukraińskiej za granicą na odcinku politycznym i ekonomicznym, wykorzystanie sprzężeń zwrotnych i efektu kuli śniegowej w rosyjskich akcjach propagandowych, dalsze intensywne wspieranie finansowe i eksperckie przez Rosjan instytucji, organizacji i mediów ukraińskich, zajmujących się tematyką Międzymorza. Natomiast na poziomie wewnątrzkrajowym: akcentowanie kryzysu politycznego, eskalacja, nagłaśnianie i inspirowanie skandali politycznych, wykorzystanie kwestii dywersyfikacji energetycznej i reform całego sektora, ataki finansowe, spekulacyjne (w tym na ukraińską walutę), destabilizacja sytuacji zwłaszcza $w$ granicznych obwodach, inspirowanie, eskalacja i wzmacnianie podziałów na tle religijnym i wyznaniowym, wykorzystanie struktur paramilitarnych oraz świata przestępczego. Poza tym: powrót do tematu dwujęzyczności Ukrainy, który zapewne połączony będzie z kwestią polityki Kijowa wobec okupowanych obecnie regionów obwodu ługańskiego i donieckiego oraz okupowanego Krymu, ataki hakerskie na ukraińską infrastrukturę krytyczną oraz militarną, kontynuacja operacji z obszaru wojny informacyjnej i psychologicznej przez rosyjskie media do ukraińskiego społeczeństwa, środowiska eksperckiego, dziennikarzy, naukowców, wojskowych i poszczególnych grup społecznych, zwłaszcza rosyjskojęzycznych ${ }^{320}$.

\footnotetext{
319"Financial Times": Dwóch bylych funkcjonariuszy rosyjskich stużb winnych zabójstwa Litwinienki, https://telewizjarepublika.pl/financial-times-dwoch-bylych-funkcjonariuszy-rosyjskich-sluzb-winnychzabojstwa-litwinienki,22264.html, [dostęp 6.03.2020 r.].

${ }^{320} \mathrm{~A}$. Lelonek, Rosyjska agresja wobec Ukrainy w 2017 roku [PROGNOZA], https://www.defence24.pl/rosyjska-agresja-wobec-ukrainy-w-2017-roku-prognoza, [dostęp 6.03.2020 r.]
} 
Stosować takie narzędzie mogą tylko odpowiednio przygotowane, wyposażone i przeszkolone organizacje, posiadające wsparcie ze strony państwa. W szczególności chodzi tu o wyposażenie w odpowiednie narzędzie prawne, a mówiąc precyzyjnie ich brak.

Celem niniejszego artykułu jest uzyskanie odpowiedzi na pytanie, w jakich obszarach rosyjskie służby specjalne uczestniczą w realizacji polityki wielkomocarstwowej Rosji. Hipoteza badawcza postawiona przez autora zakłada, że służby specjalne Rosji są podstawowym narzędziem kreowania wizerunku Rosji na świecie, co wynika z uwarunkowań historycznych oraz szczególnej pozycji rosyjskich służb specjalnych w systemie bezpieczeństwa tego kraju. Dla jej potwierdzenia podjęta zostanie próba odpowiedzi na następujące pytania:

1. W jaki sposób rosyjskie służby specjalne wykorzystywane były na przestrzeni dziejów historycznych tego kraju?

2. Jaka jest pozycja służb specjalnych Rosji w okresie rządów Władimira Putina?

3. Na jakim poziomie profesjonalizmu funkcjonują służby specjalne w Rosji?

\section{Historyczne uwarunkowania rozwoju rosyjskich służb specjalnych.}

Śledząc historię polityczną Rosji nie sposób oprzeć się wrażeniu, iż historia tego kraju nierozerwalnie związana jest z historią służb specjalnych. Początki zinstytucjonalizowanych form aktywności służb specjalnych umieszczane są w różnych okresach historii państwa. Na potrzeby niniejszego opracowania przyjęto, iż opricznina założona przez cara Iwana IV stanowi dobry przykład roli, jaką w Rosji pełnią służby specjalne. Car, dla stłumienia wewnętrznej opozycji oraz umocnienia swojej władzy, powołał 6000 organizację składająca się z młodych osób pochodzących z rodzin bojarów i dworzan. Car przykładał dużą wagę do selekcji odpowiednich kandydatów i osobiście uczestniczył w ich naborze. Wybierał kandydatów spoza starych rodów bojarskich i dworskich, chętnych zerwać wszelkie kontakty z rodzinami. Istotnym argumentem była również gotowość wykonywania wszelkich poleceń cara, czego dowód dali w 1570 roku po wkroczeniu do Nowogrodu Wielkiego. Miasto, w opinii cara, stanowiło zagrożenie dla jego pozycji i w związku z tym na jego rozkaz wymordowano 10000 mieszkańców ${ }^{321}$. Bardzo szybko opricznicy stali się narzędziem terroru, dokonując morderstw, przesiedleń oraz wszelkich form ciemiężenia Rosjan, oraz przejmowania ich majątków ${ }^{322}$.

\footnotetext{
${ }^{321}$ M. Minkina, FSB Gwardia Kremla, Warszawa 2016 r., s. 11.

${ }^{322}$ G. Rosłan, Rola Gwardii Narodowej Federacji rosyjskiej w systemie bezpieczeństwa Rosji, „Modern Management Review" 2017 r., s. 169.
} 
Utrzymanie panowania carów wymagało posiadania silnych i bezwzględnych służb mających zapewnić bezpieczeństwo oraz autorytarną władzę. Do takich należała OchranaOddział ochrony porządku i bezpieczeństwa publicznego, założona przez cara Aleksandra III na mocy ukazu z dnia 14 sierpnia 1881 roku. Bezpośrednim powodem jej powołania było zabójstwo poprzedniego cara Aleksandra II. Ochrana pozostała narzędziem carów w zakresie ich bezpieczeństwa aż do upadku caratu, tj. zabójstwa cara Mikołaja II i jego rodziny. Służba ta wsławiła się wprowadzeniem metod prowokacji politycznych w stosunku do przeciwników władzy carskiej. Formalnie podlegała Ministerstwu Spraw Wewnętrznych, posiadała przy tym bardzo szerokie kompetencje. Najważniejsze to brak kontroli ze strony parlamentu oraz sądów. Zadania tej służby to:

- zapobieganie przestępstwom wymierzonym w państwo, głównie władzę i pozycję carów,

- kontrola cudzoziemców mieszkających w Rosji, w tym szczególnie Żydów,

- nadzorowanie funkcjonowania stowarzyszeń, organizacji i klubów poprzez zatwierdzanie ich statutów oraz wydawanie zezwoleń na wszelkiego rodzaju aktywność publiczną, w tym koncerty odczyty, konferencje itp.,

- polityka paszportowa.

Ponadto funkcjonariusze tej służby decydowali o wielu błahych i wydawałoby się nieistotnych sprawach takich jak zgoda na odbycie podróży na odległość większą niż 25 kilometrów, wykonywanie młocki zboża w nocy przy zapalonych świecach czy zgody na zakup określonych leków. Możliwości służby sięgały również poza granice kraju gdzie odpowiednio wyszkolone i wyposażone zespoły zajmowały się kontrolą ugrupowań rewolucyjnych głównie z Narodnej Woli, a w późniejszym okresie również członków Partii Socjalistów-Rewolucjonistów. Centrala międzynarodowej działalności znajdowała się w Paryżu. Agentura działała w Szwajcarii, Wielkiej Brytanii, Austro-Węgrzech i na Bałkanach $^{323}$.

Totalitarne zasady kontroli państwa ukształtowane przez Ochranę praktycznie bez zmian zostały przejęte przez bolszewików i ich system kierowania państwem. Już sam sposób przejęcia i utrzymania przez nich władzy w 1917 roku odbył się w warunkach dalece odbiegających od zasad demokratycznych. Bolszewicy uzyskali w wyborach do Konstytuanty 175 mandatów w 707 osobowym parlamencie. Mimo to, wykorzystując uzbrojone oddziały,

\footnotetext{
323 Dwóch bylych funkcjonariuszy rosyjskich służb winnych zabójstwa Litwinienki, za: https://telewizjarepublika.pl/financial-times-dwoch-bylych-funkcjonariuszy-rosyjskich-sluzb-winnychzabojstwalitwinienki,22264.htm, (6.03.2020), s. 33-34.
} 
doprowadzili do rozwiązania Zgromadzenia Konstytucyjnego, przejmując $\mathrm{w}$ ten sposób władzę w państwie. Mając świadomość, iż tylko przemocą będą w stanie utrzymać władzę, już na miesiąc przed wspomnianym użyciem siły w stosunku do Konstytuanty, powołali Wszechrosyjską Komisję Nadzwyczajną przy Radzie Komisarzy Ludowych do Walki z Kontrrewolucją i Sabotażem (WCzK). Jej szefem został Feliks Dzierżyński, który bardzo szybko doprowadził do rozszerzenia jej uprawnień. Początkowo ograniczone były do prowadzenia śledztw związanych z kontrrewolucją i sabotażem, do których zaliczano także robotnicze strajki i spekulacje. WCzK uzyskała uprawnienia do aresztowania, sądzenia i karania, włącznie z karą śmierci. Codziennością stały się masowe aresztowania, zsyłki do obozów pracy czy pozbawianie majątków. Służba często stosowała represje w postaci publikowania list przeciwników komunistycznego ładu oraz zbiorowe egzekucje ${ }^{324}$. Sposób traktowania problemów bezpieczeństwa oraz osób zatrzymywanych doskonale oddają słowa bliskiego współpracownika Dzierżyńskiego Martina Janowicza Lacisa opublikowane w oficjalnym piśmie WCzK:

"Nie prowadzimy wojny z poszczególnymi osobami. Wyniszczamy burżuazję jako klasę. W śledztwie nie szukamy dowodów, że oskarżony $w$ słowie lub czynie występowat przeciwko władzy sowieckiej. Pierwsze pytania, jakie należy zadawać, to: Do jakiej klasy należysz? Jakie masz pochodzenie? Jakie masz wyksztatcenie lub jaki zawód? To sa pytania, które powinny zadecydować o losie oskarżonego. W tym właśnie leży znaczenie i sedno czerwonego terroru."

W 1923 roku WCzK zmieniło nazwę na Zjednoczony Państwowy Zarząd Polityczny (OGPU). Zmiana nazwy nie zmieniła metod postępowania. Terror stał się stałym elementem życia w Związku Socjalistycznych Republik Radzieckich. Represjom poddano chłopów, narzucając im niemożliwe do zrealizowania kontyngenty oraz zmuszając do oddawania ziemi kołchozom. Oporni byli traktowani bezwzględnie, zsyłkami oraz morderstwami. Do społeczeństwa wysyłano sygnał o tzw. kułakach, czyli bogatych chłopach wrogo nastawionych do władzy radzieckiej oraz ukrywających płody rolne przed społeczeństwem. Polityka ta w latach 1930-1937 doprowadziła do pozbawienia życia z powodu terroru czy głodu około 14,5 miliona chłopów $\mathrm{z}$ terenów Ukrainy, Kaukazu czy Białorusi ${ }^{325}$. Zastosowanie tak okrutnych metod w stosunku do niewinnych i bezbronnych ludzi stało się sposobem na pozbawienie funkcjonariuszy policji politycznej jakichkolwiek zasad moralnych oraz pełne uzależnienie ich od organów władzy. Stalin założył, że podstawą jego władzy jest

\footnotetext{
${ }^{324}$ M. Minkina, FSB Gwardia ..., op.cit. s. 16.

${ }^{325}$ R. Conquest, The Harvest of Sorrow: Soviet Collectivization and the Terror-Famine, New York 1986, s. 306.
} 
utrzymywanie całego społeczeństwa w ciągłym strachu, włącznie z przedstawicielami aparatu władzy, dowódcami wojskowymi oraz funkcjonariuszami służb. W Rosji radzieckiej okresu rządów Józefa Stalina odgórnie planowano ile osób ma być zamordowanych, nie zastanawiając się nad opinią społeczeństwa czy uzasadnieniem takich decyzji. Społeczeństwo zostało tak sparaliżowane strachem, iż władza zupełnie nie obawiała się jego reakcji. Taką masową czystkę Stalin zaplanował w sierpniu 1937 roku. Dokonano 4000 zabójstw w Leningradzie i 5000 w Moskwie. Po rozpoczęciu ,akcji” okazało się, że w Leningradzie do końca 1937 roku wymordowano ponad 19000 osób. W 1938 roku kolejna fala mordów została zorganizowana na Ukrainie, Białorusi, dalekim Wschodzie. Zdegenerowane władze lokalne, chcąc wykazać swoją gorliwość oraz oddanie Stalinowi, zwracały się z prośbą o przyznanie wyższych kontyngentów na ilość obywateli przeznaczonych do likwidacji. Nikołaj Jeżow, który ówcześnie był szefem Ludowego Komisariatu Spraw Wewnętrznych ZSRR (NKWD), ze spokojem komentował, iż nie należy się przejmować, jeżeli w wyniku tej operacji zginie tysiąc osób niewinnych ${ }^{326}$.

Po śmierci Stalina przeprowadzono jedynie fasadowe zmiany. $Z$ jednej strony potępiając jego politykę, $\mathrm{z}$ drugiej nie rezygnując $\mathrm{z}$ aparatu policji politycznej. Nikita Chruszczow, przejmując władzę po Stalinie, potępił represje NKWD, ale jedynie w stosunku do członków partii, zupełnie nie wspominając o milionach zamordowanych lub uwięzionych obywateli państwa radzieckiego. Ponadto winą obarczył Józefa Stalina i Ławrientija Berię, zdejmując $\mathrm{w}$ ten sposób odpowiedzialność $\mathrm{z}$ organów państwowych. Powołano, w miejsce Ministerstwa Bezpieczeństwa Państwowego (spadkobiercy WCzK i NKWD), Komitet Bezpieczeństwa Państwowego przy Radzie Ministrów ZSRR (KGB). W całym okresie swojego funkcjonowania organ ten nadzorował niemal wszystkie formacje radzieckich służb specjalnych, z wyjątkiem GRU podlegającemu Sztabowi Generalnemu Armii Radzieckiej. Zgodnie ze statutem KGB jego zadania to:

a) prowadzenie pracy wywiadowczej w krajach kapitalistycznych,

b) walka ze szpiegowską, dywersyjną, terrorystyczną i inną destrukcyjną działalnością zagranicznych organów wywiadowczych, zewnętrznych ośrodków antyradzieckich oraz z ich agenturą wewnątrz kraju,

c) walka $\mathrm{z}$ wrogą działalnością antyradzieckich i nacjonalistycznych elementów wewnątrz ZSRR,

d) prowadzenie pracy kontrwywiadowczej w Armii Radzieckiej, Flocie Wojenno

\footnotetext{
${ }^{326}$ M. Minkina, FSB Gwardia..., op.cit. s. 18-19.
} 
Morskiej, cywilnych liniach lotniczych, wojskach pogranicznych oraz wojskach Ministerstwa Spraw Wewnętrznych, w celu uprzedzenia przenikania w ich szeregi agentury wywiadów zagranicznych i innych wrogich elementów,

e) prowadzenie pracy kontrwywiadowczej w obiektach specjalnych, szczególnie ważnych obiektach przemysłowych oraz transporcie,

f) ochrona granic państwowych ZSRR,

g) ochrona przywódców partii i rządu,

h) organizacja i zabezpieczenie łączności rządowej,

i) organizacja pracy radiokontrwywiadowczej i rejestracji niezbędnych danych radiostacji resortowych czynnych na terytorium kraju,

j) opracowanie planów rozwinięcia mobilizacyjnego organów bezpieczeństwa państwowego i wojskowych części komitetu oraz realizowanie innych poleceń KC KPZR i rządu ZSRR ${ }^{327}$.

Oficjalnie KGB podlegała Komitetowi Centralnemu Komunistycznej Partii Związku Radzieckiego. W praktyce jednak bezpośredni nadzór nad nim sprawował sekretarz generalny KPZR za pośrednictwem zaufanych funkcjonariuszy sektora organów bezpieczeństwa państwowego.

Nabór do służby w KGB odbywał się zgodnie ze ściśle przyjętymi regułami. Przeszkodą było posiadanie rodziny w krajach kapitalistycznych, pochodzenie żydowskie, wyznawanie jakiejkolwiek religii czy też wyrażanie najmniejszych negatywnych opinii na temat państwa radzieckiego. Wymogi to odbycie służby wojskowej i niekaralność. Kandydatów do służby poszukiwano wśród absolwentów wydziałów prawa, kierunków humanistycznych. Natomiast do pracy w wywiadzie - kierunków filologicznych i stosunków międzynarodowych. W ramach procedury naboru przeprowadzano sprawdzenia kandydata i jego rodziny, poddawano go badaniom poligraficznym, a nawet stosowano podsłuch telefoniczny oraz kontrolę korespondencji. Tę trudną drogę uzyskania zatrudnienia w KGB rekompensowały późniejsze przywileje oraz pensja przekraczającą dwukrotnie średnią pensję w przemyśle, a nawet trzykrotnie w sektorze rolnictwa. Pewną niewiadomą pozostaje liczba wszystkich zatrudnionych w różnych okresach w służbie. Dane pochodzą od zbiegłych na zachód oficerów KGB, informacji służb wywiadowczych państw kapitalistycznych oraz źródeł państwowych po upadku ZSRR, co do których można mieć wątpliwości odnośnie ich

\footnotetext{
${ }^{327}$ L. Pawlikowicz, Tarcza i miecz - od rozkwitu do upadku: podstawowe funkcje, struktury, potencjat kadrowy oraz obsada personalna Komitetu Bezpieczeństwa Państwowego (przy Radzie Ministrów) ZSRR w latach 19751991, Aparat Represji w Polsce Ludowej 1944-1989, nr 1(10), 2012 r., s. 16.
} 
rzetelności. Najwięcej specjalistów podaje ilość około 500000 oficerów operacyjnych, funkcjonariuszy służb granicznych oraz zatrudnionych w Zarządzie Łączności Radiowej ${ }^{328}$.

Trudnym zadaniem jest ocena skuteczności oraz profesjonalizmu służb specjalnych. Nieco łatwiej jest to zrobić, gdy odbywa się to z perspektywy historycznej lub informacje pochodzą z raportów innych służb. W odniesieniu do KGB, w 1984 roku, Centralna Agencja Wywiadowcza opracowała ściśle tajny raport dotyczący wywiadu radzieckiego KGB i GRU. Analiza dotyczyła struktur, środków, metod, sposobów działania obu wymienionych służb. W raporcie mówi się o 3000 oficerów operacyjnych działających z pozycji placówek dyplomatycznych, dążących do uzyskania źródeł informacyjnych na poziomie struktur rządowych, resortów siłowych w około stu państwach, w tym USA, Chinach i państwach NATO. W latach 1975-1991 pozyskali do współpracy czterech oficerów CIA oraz trzech FBI. Mimo, że liczby nie sugerują wybitnych sukcesów w wykonaniu 3000 specjalistów z zakresu werbowania źródeł, to tym sposobem KGB sparaliżował wszystkie operacje służb zachodnich państw na terenie Związku Radzieckiego przez ostatnie 6 lat jego istnienia.

\section{Pozycja rosyjskich służb specjalnych w okresie rządów Wladimira Putina.}

Upadek ZSRR nie stał się upadkiem rosyjskich służb specjalnych w wydaniu totalitarnym. Służby specjalne Federacji Rosyjskiej zwiększają posiadane uprawnienia, m.in. dokonują cenzury publikacji w kraju, również mediów cyfrowych. Nadal prześladowani są przeciwnicy polityczni, opozycyjni dziennikarze, włącznie $\mathrm{z}$ morderstwami tych najbardziej niepokornych. Obecnie ranga służb specjalnych Rosji wynika z pozycji jej byłego oficera Władimira Putina oraz wielu innych byłych i czynnych funkcjonariuszy obecnych W strukturach administracji rządowej oraz sferze gospodarczej ${ }^{329}$.

Władimir Putin został dyrektorem FSB w czerwcu 1998 roku mając za sobą 23 lata doświadczenia, m. in. na placówce w Dreźnie. Zajmował się tam najprawdopodobniej pozyskiwaniem osobowych źródeł wśród funkcjonariuszy Ministerstwa Bezpieczeństwa Państwowego Niemieckiej Republiki Demokratycznej (powszechnie zwanej Stasi), członków Niemieckiej Socjalistycznej Partii Jedności oraz obywateli Republiki Federalnej Niemiec prowadzących na terenie Niemieckiej Republiki Demokratycznej interesy lub studiujących w tamtejszych uczelniach. Putin natychmiast po objęciu stanowiska podjął działania mające na celu podniesienie znaczenia i rangi służby. Podczas wystąpienia w Dumie przedstawił

\footnotetext{
${ }^{328}$ Ibidem, s. 20-21.

${ }^{329}$ M. Minkina, FSB Gwardia..., op.cit., s. 30.
} 
priorytety oraz zadania służby pod jego zwierzchnictwem ${ }^{330}$. Jednocześnie w wystąpieniu telewizyjnym wychwalał czyny WCzK, nie wspominając ani słowem o przestępczej stronie jej działalności. Umieścił również w gmachu FSB, usuniętą w 1991 roku, tablicę upamiętniającą byłego szefa KGB, a późniejszego pierwszego sekretarza Komunistycznej Partii Związku Radzieckiego (KPZR), Jurija Andropowa ${ }^{331}$. W ten sposób wysłał jednoznaczny sygnał o kontynuacji tradycji i sposobu działania radzieckich, a nawet carskich służb specjalnych. Równocześnie Putin rozpoczął proces budowania wizerunku oficera rosyjskich służb, osoby profesjonalnej, oddanej sprawom państwowym o nieskazitelnych walorach moralnych. Świetnie oddaje to wypowiedź Nikołaja Patruszewa z 2000 roku, gdy pełnił funkcje dyrektora FSB. W wywiadzie udzielonym „Komsomolskiej Prawdzie” powiedział:

"Kiedy wręczam moim ludziom nagrody, badam uważnie ich twarze. Sa to wysoko wykwalifikowani analitycy, dobrze zbudowani, silni żolnierze specnazu, cisi specjaliści od materiatów wybuchowych, bardzo wnikliwi śledczy, dyskretni pracownicy operacyjni kontrwywiadu... Na zewnątrz sq oni różni, ale jest jedna cecha, która ich łączy: poczucie obowiązku stużby, jeśli chcecie współczesna nowa szlachta."

Służby wnikliwie śledziły nastroje społeczne oraz sposób postrzegania służb przez obywateli. Gdy pojawiły się opinie o zamkniętej korporacji przejmującej władze w państwie, służby prasowe zareagowały bardzo szybko. Wykreowały wizerunek elitarnej grupy patriotów o propaństwowych poglądach, której obecność w strukturach państwa pozwoli na odbudowanie rosyjskiej potęgi. Dodatkowo obraz ten wspierano wieloletnią tradycją służb specjalnych odgrywających ważną i pozytywną rolę w historii państwa rosyjskiego.

Mimo wieloletniej wojny administracji państwowej oraz jej instytucji z kościołem prawosławnym pozycja prawosławia w Rosji, szczególnie po upadku Związku Radzieckiego, jest mocno ugruntowana. Wykorzystał to Putin, aby swoją pozycję wesprzeć również autorytetem cerkwi. W marcu 2002 roku na terenie siedziby FSB poświęcono świątynię prawosławną w obecności patriarchy Aleksieja II oraz dyrektora FSB. Znamienne znaczenie ma napis umieszczony na ścianie świątyni:

Świątynia Mądrości Bożej na Eubiance została odbudowana z błogosławieństwem patriarchy Moskwy i Wszechrusi i dzięki gorliwości Federalnej Stużby Bezpieczeństwa ${ }^{332}$

\footnotetext{
${ }^{330}$ Ibidem, s. 37.

${ }^{331}$ M. Kaszuba, Carsko-sowiecka mitologia rosyjskich stużb specjalnych, „Studia Politologiczne” 2017, nr 43, s. 230.

${ }^{332}$ Ibidem, s. 231.
} 
Putin, czerpiąc z doświadczeń władców Rosji oraz Związku Radzieckiego, pamięta o potrzebie wprowadzania okresowych zmian, wprowadzających efekt rozedrgania mający utrzymywać cały aparat państwowy w atmosferze niepewności oraz przeświadczeniu o uzależnieniu od jednej osoby tj. prezydenta Federacji Rosyjskiej. Dla realizacji tego efektu oraz skupienia pełnej kontroli nad służbami w jednym miejscu 11 marca 2003 roku prezydent podpisał dekret o połączeniu z FSB Federalnej Służby Pogranicza, oraz Federalnej Służby Łączności Rządowej i Informacji. W ten sposób FSB stała się federalnym organem władzy wykonawczej, który w swoich kompetencjach odpowiada za bezpieczeństwo państwa obronę i ochronę granicy państwowej FR, ochronę wewnętrznych wód morskich oraz bezpieczeństwo informacyjne. Ze względu na swoją pozycję koordynuje również działalność kontrwywiadowczą pozostałych federalnych organów władzy wykonawczej ${ }^{333}$. To, co wyraźnie wyróżnia FSB spośród innych służb szczególnie w państwach demokratycznych to całkowity brak nadzoru i kontroli ze strony władzy ustawodawczej oraz organów kontroli państwowej. Jedyna realna podległość to prezydent Rosji.

Wśród typowych zadań służby specjalnej na specjalną uwagę zasługuje walka informacyjna w cyberprzestrzeni, do której oficjalnie żadna ze służb nie przyznaje się, natomiast wiele $\mathrm{z}$ nich realnie ją prowadzą. W tym zakresie FSB jest doskonale przygotowana i to zarówno w zakresie obrony, jak i działań ofensywnych. Od 2002 roku funkcjonuje Centrum Bezpieczeństwa Informatycznego FSB, do którego zadań należy:

- analiza zagrożeń bezpieczeństwa informacyjnego Rosji,

- wykrywanie, ostrzeganie oraz przeciwdziałanie szpiegostwu w cyberprzestrzeni,

- wykrywanie, ostrzeganie oraz przeciwdziałanie przestępczości w cyberprzestrzeni ${ }^{334}$.

Realizacja tego typu zadań daje duże uprawnienia sięgające możliwości kontroli wszelkiej aktywności w sieci oraz pozyskiwania od właścicieli portali, oraz dostawców usług internetowych, informacji na temat osób korzystających $\mathrm{z}$ internetu czy autorów umieszczanych tam materiałów. Rosyjskie służby oskarżane są o przeprowadzenie wielu spektakularnych ataków cybernetycznych na infrastrukturę krytyczną innych państw. Między innymi w 2007 roku w Estonii, jako odpowiedź na usunięcie pomnika tzw. Brązowego Żołnierza (który upamiętniał radzieckich wojskowych poległych w bitwie o odbicie Tallinna), serwery rządu estońskiego zostały masowo zaatakowane przez niezależnych hakerów z rosyjskiej organizacji "Nasi". Tak przedstawiał się podmiot prowadzący ataki. W krótkim

\footnotetext{
${ }^{333}$ J. Darczewska, P. Żochowski, Rola stużb specjalnych w systemie politycznym Federacji Rosyjskiej, „Przegląd Bezpieczeństwa Wewnętrznego" 2013, s. 23.

${ }^{334}$ M. Minkina, FSB Gwardia ..., op.cit., s. 50.
} 
czasie przestały działać strony banków, zawieszono lub zablokowano wiele transakcji online, a czytelnicy "Postimees" nie mogli wejść na stronę najpopularniejszego dziennika w kraju ${ }^{335}$. Również podczas konfliktu z Gruzją w 2008 roku zablokowane zostały strony rządowe najważniejszych gruzińskich mediów oraz przestała działać telefonia komórkowa. Analiza przeprowadzonego ataku pokazała, że uczestniczące w niej komputery znajdowały się nie tylko w Rosji, ale również na terytorium dawnego ZSRR, w tym na terenie krajów bałtyckich ${ }^{336}$.

Bezsprzecznie najlepszym dowodem na nieproporcjonalnie wysoką pozycję służb specjalnych w Rosji jest udział przedstawicieli resortów siłowych na wysokich stanowiskach w administracji państwowej, biznesie czy mediach. Proces ten realizowany jest od początku pierwszej kadencji prezydentury Putina, który dążył do ograniczenia roli ekonomistów oraz przedstawicieli przemysłu, nie godząc się na przeprowadzenie zbyt daleko idących reform wolnorynkowych. Ponadto, jako były oficer służb lepiej rozumie oraz wyznaje te same co oni wartości. Dodatkowo wśród tzw. siłowików posiada zaufane osoby, którym powierza stanowiska, nad którymi chce mieć pełną kontrolę.

\section{Profesjonalizm rosyjskich służb specjalnych.}

We wstępie do niniejszego artykułu podane zostały przykłady zabójstw dokonanych przez rosyjskie służby specjalne na osobach niewygodnych dla Rosji oraz samych służb. Trudno jest na tej podstawie stawiać tezę o wysokim poziomie profesjonalizmu tych instytucji. Natomiast takie informacje dają podstawę do oceny stopnia przestrzegania prawa oraz nadzoru nad służbami, które w XXI wieku dopuszczają się takich czynów. Generalnie próby oceny profesjonalizmu służb specjalnych są zadaniem trudnym i obarczonym wysokim prawdopodobieństwem popełnienia błędu. Wynika to z braku rzetelnych i sprawdzonych informacji na temat działalności i konkretnych zadań realizowanych przez służby. Ponadto informacje, jeżeli pojawiają się to najczęściej po upływie pewnego czasu od konkretnego wydarzenia oraz nie znajdują oficjalnego potwierdzenia ze strony samych służb.

Aktualnie oceny stopnia poziomu wyszkolenia oraz skuteczności służb rosyjskich możemy dokonać na podstawie takich wydarzeń jak aneksja Krymu, oraz operacja na terenie wschodniej Ukrainy. Tłem do podjętych kroków przez Rosję było niebezpieczne zbliżenie

\footnotetext{
${ }^{335} \mathrm{~J}$. Stolarczyk, Estonia - pierwsza ofiara cybernetycznej wojny, https://wiadomosci.onet.pl/tylko-wonecie/estonia-pierwsza-ofiara-cybernetycznej-wojny/t3czdg5, [dostęp19.03.2020 r.].

${ }^{336}$ Kto $i$ z kim walczy na frontach cyfrowych?, https://pl.sputniknews.com/swiat/201510141218682-USAcyberatak-Rosja/, [dostęp 19.03.2020 r.].
} 
Ukrainy z NATO i Unią Europejską oraz chęć uzyskania niezagrożonego dostępu do akwenu Morza Śródziemnego dla floty czarnomorskiej. Cały kompleks podjętych czynności to wojna informacyjno-psychologiczna, która zrealizowana została w przeważającej części przez służby specjalne. W ramach wspomnianej operacji przeprowadzono działania medialne, dyplomatyczne, finansowo-ekonomiczne i wojskowe. Wszystko zostało zaplanowane dużo wcześniej. Przykładem takiego działania może być między innymi wsparcie sprzyjającego Rosji prezydenta Ukrainy Wiktora oraz jego obozu w 2003 i 2004 oraz 2010 roku. Zadbano też o prezentowanie Ukrainy, jako państwa czasowego, bez odpowiednich podstaw państwowości oraz mocno spolaryzowanym społeczeństwie ${ }^{337}$. Przyjęto trzy możliwe warianty rozwoju sytuacji:

1. Podział Ukrainy na dwie strefy: zachodnią i południowo-wschodnią, czego pretekstem miałoby być uniknięcie rzekomo realnej groźby wybuchu wojny domowej.

2. Prowadzenie dialogu $\mathrm{z}$ władzami Ukrainy $\mathrm{w}$ celu przekonania ich do pozostania w sferze wpływów rosyjskich, przy użyciu argumentów siły, ekonomicznych czy politycznych.

3. Wykorzystanie nacjonalistów głównie z Ukrainy Zachodniej, zachowujących dystans w zakresie przestrzegania praw człowieka, wielokulturowości, liberalizmu czy tolerancji ${ }^{338}$.

Według generała majora Aleksandra Michajłowa, byłego szefa Zarządu FSB ds. kontaktów ze społeczeństwem, na Ukrainie zastosowano szereg elementów działań informacyjnych, między innymi działania psychologiczne w postaci presji i zastraszania. Ponadto w wojnie informacyjno-psychologicznej przewidziano udział najwyższych przedstawicieli władz (w tym przypadku prezydenta Putina), formę szantażu oraz sankcji. Generał zwrócił również uwagę na równoległe prowadzenie operacji w rzeczywistości realnej oraz $\mathrm{w}$ świecie wirtualnym, co dodatkowo pozwoliło ograniczyć reakcje przeciwnika oraz wzmocnić elementy nacisku. Działania zbrojne żołnierzy wojsk specjalnych i aeromobilnych Sił Zbrojnych Federacji Rosyjskiej, tzw. zielonych ludzików, prezentowano w mediach rosyjskich oraz światowych, ale tylko tych, na które rosyjskie służby posiadają wpływ jako „krymskie siły samoobrony”, mające zapobiec krwawym zajściom, jakie miały miejsce na kijowskim Majdanie ${ }^{339}$.

\footnotetext{
${ }^{337}$ J. Darczewska, Anatomia rosyjskiej wojny informacyjnej. Operacja krymska - studium przypadku, Ośrodek Studiów Wschodnich im. Marka Karpia, Warszawa 2014, s. 21.

${ }^{338}$ A. Bień-Kacała, T. Kacała, Działania psychologiczno-dezinformacyjne rosyjskich stużb specjalnych, „Studia Politologiczne" 2017, nr 43, s. 157.

${ }^{339}$ Ibidem, s. 158.
} 
Wydarzenia związane $\mathrm{z}$ wyborami prezydenckimi w Stanach Zjednoczonych w 2016 roku dowiodły, jak potężnymi narzędziami dysponują służby rosyjskie. 7 października 2016 roku do amerykanów dotarło 18000 specjalnie spreparowanych informacji. Tego samego dnia portal Wikileaks zaczął publikować zawartość wykradzionych ze sztabu wyborczego Hilary Clinton skrzynek pocztowych. Za całą operacją stała Państwowa Agencja Badania Internetu z Sankt Petersburga, której właścicielem jest osoba związana z Władimirem Putinem. Odniesienia do informacji wysyłanych za pośrednictwem Agencji, tylko w ciągu września, października i listopada 2016 roku, pojawiły się w tweetach innych użytkowników 4,7 miliona razy ${ }^{340}$.

Rosyjskie służby specjalne odegrały również znaczącą rolę $\mathrm{w}$ sprawie wyjścia Wielkiej Brytanii z Unii Europejskiej. Dowodzi tego przechwycona przez służby brytyjskie korespondencja biznesmena Arrona Banksa, z której wynika, że utrzymywał relacje z ambasadorem Federacji Rosyjskiej w Wielkiej Brytanii. Banks uzyskał trzy wysoce opłacalne kontrakty biznesowe $\mathrm{w}$ okresie kampanii referendalnej i jednocześnie wsparł kampanię Leave.EU dotacją w wysokości 8 milionów funtów ${ }^{341}$.

Operacje informacyjne to $\mathrm{z}$ pewnością mocna strona rosyjskich służb. Natomiast ocenie należy również poddać system naboru do służby, szkolenia oraz poziom ogólnej dyscypliny jej funkcjonariuszy. W Rosji szansę na dostanie się w szeregi „,nowej szlachty” mają głównie dzieci funkcjonariuszy lub innych wysokich urzędników państwowych. $\mathrm{Z}$ jednej strony daje to większą gwarancję zaufania do osoby wychowywanej od dzieciństwie w atmosferze dyscypliny i swego rodzaju odpowiedzialności. Z drugiej strony może pojawić się problem odpowiednich predyspozycji takich osób przyjmowanych „,po znajomości”. Trudno założyć, że dziecko ważnego notabla zostanie odrzucone na którymś z etapów naboru do służby. Sama procedura naboru zbliżona jest do procedur kadrowych w służbach innych państw, obejmująca między innymi badania lekarskie, testy psychologiczne oraz badania poligraficzne.

Odrębną kwestią pozostaje problem korupcji wśród funkcjonariuszy rosyjskich służb. Informacje dotyczące tego problemu często są sprzeczne i niepełne, z pewnością jednak korupcja to stały element, w instytucjach nie podlegających żadnej kontroli. Ponadto przekonanie funkcjonariuszy o ich wyjątkowej pozycji w społeczeństwie i ponadczasowej misji, może usprawiedliwiać niezgodne z prawem zachowania. Do tego dochodzi jeszcze

\footnotetext{
${ }^{340} \mathrm{P}$. Ogrodowczyk, ,'Środki aktywne” - skuteczne działania rosyjskich służb specjalnych, „Civitas Hominibus” 2018, nr 13, s. 70.

${ }^{341}$ Ibidem, s. 70.
} 
element powszechnej i akceptowanej w Rosji korupcji, szczególnie wśród przedstawicieli administracji państwowej, członków rządu oraz biznesu. W jednej $\mathrm{z}$ wypowiedzi wicedyrektor FSB mówił o przepełnionych koloniach karnych dla funkcjonariuszy oraz potrzebie budowania nowych, aby uniknąć w nich potencjalnych buntów ze względu na pogarszające się warunki życia ${ }^{342}$.

\section{Podsumowanie.}

Analiza historii pozycji oraz poziomu profesjonalizmu rosyjskich służb specjalnych dowodzi ich wysokiej pozycji w systemie kierowania państwem. Prezydent Putin, który mentalnie związany jest ze służbami, na nich opiera swój sposób kierowania państwem. Sprzyja temu społeczna akceptacja wynikająca z obecności służb w życiu Rosjan praktycznie od średniowiecza. Putin doskonale rozumie rosyjskie społeczeństwo potrzebujące silnego przywódcy, nawet za cenę ograniczenia wolności czy niskiego poziomu życia. W takiej sytuacji nawet nadużycia czy korupcja wśród przedstawicieli resortów siłowych jest łatwo wybaczana ze strony społeczeństwa. Prezydent, wraz ze wspierającymi go „siłowikami”, doskonale radzi sobie z sytuacją wewnętrzną kraju dzięki poważnemu ograniczeniu roli mediów nieprzychylnych władzy oraz opozycji politycznej. Natomiast mocno rozwinął aparat propagandy ze strony przychylnych mu mediów oraz akcji informacyjnych prowadzonych za pośrednictwem telewizji, prasy czy internetu. Ważnym elementem tego procesu są służby specjalne.

Dzięki polityce kadrowej, opierającej się na pełnym uzależnieniu pozycji szefów służb od lojalności wobec Putina, nie ma problemu nadmiernego wzrostu pozycji poszczególnych osób dążących do uzyskania samodzielności, nie mówiąc już o zagrożeniu pozycji prezydenta. Również dla uniknięcia zbytniego wzrostu znaczenia jakiejkolwiek ze służb przeprowadza okresowe reformy zmieniające zakres zadań czy też ich uprawnień. Jednym z ostatnich tego typu posunięć był dekret z 27 lutego 2018 roku zwiększający uprawnienia Federalnej Służby Ochrony (FSO) odpowiedzialnej za ochronę przedstawicieli władzy, oraz najwyższych urzędników administracji państwowej. W regulaminie służby pojawił się zapis: ,$w$ ramach swych kompetencji uczestniczy $w$ realizacji międzynarodowej polityki bezpieczeństwa informacyjnego, realizacji przedsięwzięć $w$ ramach walki informacyjnej,

\footnotetext{
${ }^{342}$ J. Darczewska, Między jawna dezinformacja a niejawna praktyką. Gry rosyjskich stużb, Ośrodek Studiów Wschodnich im. Marka Karpia, Warszawa 2019, s. 15-16.
} 
a także działań na rzecz wykrywania, zapobiegania i likwidacji skutków ataków na zasoby informacyjne FR" ${ }^{343}$.

Dominującą domeną działalności służb specjalnych w Rosji jest polityka zagraniczna, szczególnie w zakresie budowania wizerunku Rosji pozostającej w stanie permanentnego zagrożenia ze strony NATO, Unii Europejskiej czy innych instytucji międzynarodowych. Wyraźny udział służb ma miejsce w realizacji wielkomocarstwowej polityki i pozycji Rosji. Dzisiaj jedynymi podstawami wielkomocarstwowości rosyjskiej pozostają zasoby nuklearne oraz gaz i ropa. Nie przeszkadza to jednak ingerowaniu w politykę innych państw poprzez realizację operacji informacyjnych podczas wyborów, kampanii referendalnych czy też pozyskiwanie wsparcia ze strony ugrupowań politycznych. Działania te realizowane przez państwo o niskim poziomie życia obywateli, kierowane praktycznie w sposób autorytarny, skorumpowane, pozbawione mechanizmów demokratycznych, stanowią ogromne zagrożenia dla bezpieczeństwa międzynarodowego. Również sama pozycja rosyjskich służb pozbawiona kontroli ze strony instytucji państwowych, takich jak władza ustawodawcza czy sądownicza, może budzić niepokój, szczególnie w sytuacji społecznej akceptacji dla takiego stanu rzeczy.

Trudno jest przewidywać w jakim kierunku będzie zmierzała Rosja w przyszłości. Natomiast jej służby specjalne, jeżeli nie rozwiną się mechanizmy demokratycznego nadzoru i kontroli, nadal stanowić będą podstawę realizacji „brudnej” polityki zagranicznej oraz utrzymywania społeczeństwa rosyjskiego w stanie zastraszenia i niepewności.

\section{Streszczenie:}

Celem niniejszego artykułu było wskazanie pozycji rosyjskich służb specjalnych w państwie, a także poziomu ich wykorzystania $\mathrm{w}$ realizacji polityki wewnętrznej oraz zagranicznej. W tym celu zanalizowano uwarunkowania historyczne oraz pozycję służb specjalnych w Rosji w okresie rządów Władimira Putina. Podjęto również próbę oceny poziomu profesjonalizmu rosyjskich służb.

\section{Słowa kluczowe:}

Służby specjalne, Rosja, bezpieczeństwo międzynarodowe.

\section{Key words:}

Special services, Russia, international security.

\footnotetext{
${ }^{343}$ Үказ Президента Российской Федерацииот 27 февраля 2018 года № 89, О внесении и зменений в Положение о Федеральной службе охраны Российской Федерации, утвержденное Указом Президента Российской Федерацииот 7 августа 2004 г., № 1013, https://rg.ru/2018/02/27/prezident-ukaz89-site-dok.html (22.03.2020)
} 


\section{Bibliografia:}

1. Bień-Kacała A., Kacała T., Działania psychologiczno-dezinformacyjne rosyjskich służb specjalnych, Studia Politologiczne, vol. 43, 2017 r.

2. Conquest R. , The Harvest of Sorrow: Soviet Collectivization and the Terror-Famine, New York 1986.

3. Darczewska J., Anatomia rosyjskiej wojny informacyjnej. Operacja krymska studium przypadku, Ośrodek Studiów Wschodnich im. Marka Karpia, Warszawa 2014.

4. Darczewska J., Między jawną dezinformacją a niejawna praktyką. Gry rosyjskich służb, Punkt Widzenia nr 73, Ośrodek Studiów Wschodnich im. Marka Karpia, Warszawa 2019

5. Darczewska J., Żochowski P., Rola służb specjalnych w systemie politycznym Federacji Rosyjskiej, „Przegląd Bezpieczeństwa Wewnętrznego”, 2013 r.

6. "Financial Times": Dwóch byłych funkcjonariuszy rosyjskich służb winnych zabójstwa Litwinienki, https://telewizjarepublika.pl/financial-times-dwoch-bylychfunkcjonariuszy-rosyjskich-sluzb-winnych-zabojstwa-litwinienki, 22264.html, [dostęp 6.03.2020 r.]

7. Górka M., Dyplomacja i wywiad. Przyczynek do refleksji nad polityką bezpieczeństwa, [w:] G. Marek (red.), Wywiad i kontrwywiad w polityce międzynarodowej na przełomie XX i XXI wieku, Wydawnictwo Difin, Warszawa 2016.

8. Kacała T., Podstawowe założenia koncepcji komunikacji strategicznej w Siłach Zbrojnych RP, Kwartalnik „Bellona” 2015, nr 2.

9. Kaszuba M., Carsko-sowiecka mitologia rosyjskich służb specjalnych, Studia Politologiczne, vol. 43, 2017 r.

10. Kto i z kim walczy na frontach cyfrowych?, https://pl.sputniknews.com/swiat/ 201510141218682-USA-cyberatak-Rosja/ [dostęp 19.03.2020 r.]

11. Lelonek A., Rosyjska agresja wobec Ukrainy w 2017 roku [PROGNOZA], https://www.defence24.pl/rosyjska-agresja-wobec-ukrainy-w-2017-roku-prognoza, [dostęp 6.03.2020 r.]

12. Minkina M., FSB Gwardia Kremla, Oficyna Wydawnicza Rytm, Warszawa 2016 r.

13. Ogrodowczyk P., „Środki aktywne” - skuteczne działania rosyjskich służb specjalnych, Civitas Hominibus nr 13/2018.

14. Указ Президента Российской Федерацииот 27 февраля 2018 года № 89 О внесени и изменений в Положение о Федеральной службе охраны Российской Федерации, утвержденное Указом Президента Российской Федерацииот 7 августа 2004 г. № 1013 https://rg.ru/2018/02/27/prezident-ukaz89-site-dok.html [dostęp 22.03.2020 r.]

15. Pawlikowicz L., Tarcza i miecz - od rozkwitu do upadku : podstawowe funkcje, struktury, potencjał kadrowy oraz obsada personalna Komitetu Bezpieczeństwa Państwowego (przy Radzie Ministrów) ZSRR w latach 1975-1991, Aparat Represji w Polsce Ludowej 1944-1989 nr 1(10), 2012 r. 
16. Rosłan G., Rola Gwardii Narodowej Federacji rosyjskiej w systemie bezpieczeństwa Rosji, Modern Management Review 2017 r.

17. Stolarczyk J., Estonia - pierwsza ofiara cybernetycznej wojny ttps://wiadomosci.onet.pl/tylko-w-onecie/estonia-pierwsza-ofi 